\title{
Sistem Informasi Geografis Pemetaan Kerusakan Jalan Berbasis Web Dan Android
}

\author{
Nila Hafidatur Rofi'ah*1, Muchammad Faid ${ }^{2}$, Cahyuni Novia ${ }^{3}$ \\ ${ }^{1,2,3}$ Prodi Informatika Fakultas Teknik Universitas Nurul Jadid \\ Karanganyar Paiton Probolinggo \\ e-mail: ${ }^{* 1}$ syahfi841@gmail.com, ${ }^{2}$ faid@unuja.com, ${ }^{3}$ cahyuni@unuja.com
}

\begin{abstract}
Abstrak
Dinas PUPR merupakan kantor Dinas Pekerjaan Umum dan Penataan Ruang untuk wilayah Kabupaten Probolinggo. Jalan yang ditangani oleh Dinas PUPR sendiri ada jalan kabupaten. Jalan kabupaten pada database bidang binamarga berdasarkan SK terdapat 288 ruas jalan. Perbaruan data ini dilakukan setiap satu tahun sekali. Dari sistem yang ada bidang binamarga ini yaitu mencangkup semua kondisi jalan kabupaten yang ada di kabupaten probolinggo. Sehingga untuk mencari data kerusakan jalan yang ada harus membuka semua data yang ada terlebih dahulu. Kurang efisiennya dalam menemukan data kerusakan jalan ini membuat proses penangannnaya lama untuk dilakukan. Berdasarkan permasalahan tersebut peneliti merancang aplikasi pemetaan dengan menggunakan aplikasi Sistem Informasi Geografis (SIG/GIS) berbasis web dan android yang dapat mempermudah pemerintah khususnya Dinas PUPR (Pekerja Umum dan Penataan Ruang) dalam menemukan kerusakan jalan untuk melakukan perbaikan dengan cepat dan hemat. Sehingga mampu membantu Dinas PUPR dalam memetakan kerusakan jalan yang ada di Kabupaten Probolinggo guna mempermudah dalam pencarian data kerusakan jalan yang ada. Berdasarkan hasil pengujian eksternal aplikasi ini memperoleh hasil persentase sebesar $92 \%$ yang artinya sistem ini sangat baik untuk digunakan.
\end{abstract}

Kata Kunci: SIG, Pemetaan, Web, Android..

\begin{abstract}
The PUPR Service is the office of the Public Works and Spatial Planning Office for the Probolinggo Regency area. The road handled by the PUPR Service itself is a district road. There are 288 road sections in the Binamarga sector database based on the Decree. This data is updated once a year. From the existing system, the Binamarga sector covers all district road conditions in the Probolinggo district. So to look for existing road damage data, you must first open all existing data. This lack of efficiency in finding road damage data makes the handling process take a long time to do. Based on these problems, the researchers designed a mapping application using a web and android-based Geographic Information System (GIS/GIS) application that can facilitate the government, especially the PUPR Service (General Workers and Spatial Planning) in finding road damage to make repairs quickly and efficiently. So that it is able to assist the PUPR Office in mapping the existing road damage in Probolinggo Regency in order to facilitate the search for existing road damage data. Based on the results of external testing, this application obtained a percentage of $92 \%$, which means this system is very good to use.
\end{abstract}

Keywords: GIS, Mapping, Web, Android. 


\section{PENDAHULUAN}

Sesuai UU nomor 38 Tahun 2004, jalan merupakan prasarana yg ditujukan buat transportasi darat, termasuk bagian jalan, aneka macam bangunan serta perlengkapan untuk kemudian lintas, berada di atas bagian atas tanah dan pada bawah bagian atas tanah atau air, terkecuali buat jalan kereta barah, jalan lori dan jalan kabel. Sedangkan dalam UU angka 22 Tahun 2009, dijelaskan Jika jalan adalah semua bagian jalan, bangunan pelengkap dan perlengkapannya yg ditujukan buat kemudian lintas umum , berada pada atas permukaan tanah, di bawah permukaan tanah atau air, dan di atas permukaan air, terkecuali pada jalan rel dan jalan kabel [1].

Dinas PUPR ialah tempat kerja Dinas Pekerjaan umum serta Penataan Ruang buat daerah Kabupaten Probolinggo. Kedinasan ini mempunyai tugas sebagai penyelenggaraan urusan pemerintah bidang pekerjaan umum , pembangunan infrastrukur serta perumahan buat daerah Kabupaten Probolinggo, Jawa Timur[1]. Jalan yg ditangani oleh Dinas PUPR sendiri terdapat jalan kabupaten. Sedangkan buat jalan desa ditangani oleh masing-masing desa tadi. Jalan kabupaten pada database bidang binamarga sesuai SK terdapat 288 ruas jalan. Perbaruan data ini dilakukan setiap satu tahun sekali. berasal sistem yg terdapat bidang binamarga ini yaitu mencangkup semua kondisi jalan kabupaten yg terdapat pada kabupaten probolinggo. sehingga untuk mencari data kerusakan jalan yang terdapat wajib membuka semua data yang ada terlebih dahulu. Kurang efisiennya pada menemukan data kerusakan jalan ini membuat proses penangannnaya usang buat dilakukan.

Perkembangan teknologi khususnya di bidang komputer menawarkan kemajuan dan inovasi yang memberi kemudahan kepada penggunanya. Komputer juga dimanfaatkan sebagai sarana penentu letak geografis pada suatu wilayah. Salah satu sistem informasi dalam perkembangan teknologi komputer adalah aplikasi yang dapat di tangani oleh sistem informasi geografis, Di antaranya adalah Sistem Informasi Geografis yang terdiri dari perangkat lunak dan perangkat keras yang didesain untuk mengolah data yang berkaitan dengan bumi untuk menganalisis, memperkirakan dan gambaran kartografi[5]. Banyak berbagai aplikasi di bidang pemerintahan yang dapat dilakukan dengan bantuan GIS yaitu pemetaan kerusakan jalan yang dapat mempermudah pemerintah khususnya Dinas PUPR (Pekerja Umum dan Penataan Ruang) dalam menemukan kerusakan jalan untuk melakukan perbaikan dengan cepat dan hemat.

Berdasarkan uraian diatas dibutuhkan suatu sistem yang dapat memetakan kerusakan jalan kabupaten di Kabupaten Probolinggo. Sehingga dapat membantu pemerintah khususnya Dinas PUPR (Pekerja Umum dan Penataan Ruang) dalam menemukan letak kerusakan jalan kabupaten yang ada di Kabupaten Probolinggo.

\section{METODE PENELITIAN}

Dalam penelitian ini metode yang digunakan adalah untuk menghasilkan detaksi lembar jawaban computer secara otomatis sesuai dengan langkah-langkahnya. Proses dari penelitian ini meliputi Teknik Pengumpulan Data dan Teknik Pengembangan. Gambar 1 adalah gambaran kerangka penelitian. 


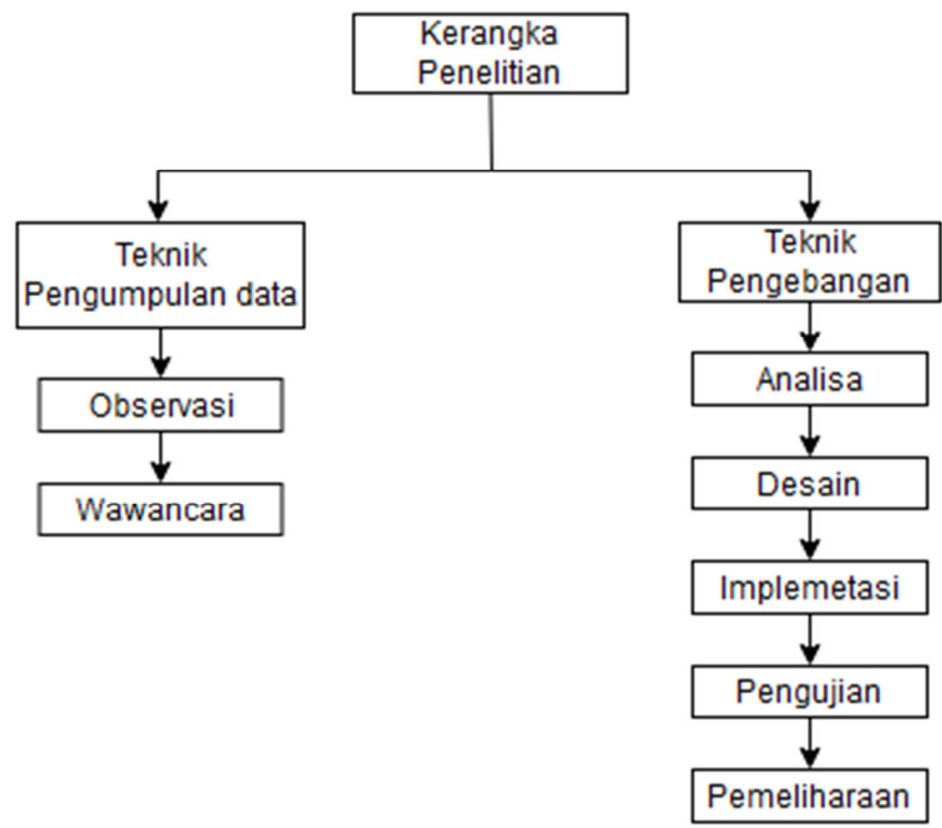

Gambar 1. Kerangka Penelitian

\subsection{Teknik Pengumpulan Data [2]}

a. Observasi

Dalam penelitian ini di lakukan dengan cara mengadakan pengamatan secara langsung terhadap objek penelitian. Adapun yang menjadi sasaran dalam observasi adalah bidang Binamarga Dinas PUPR Kabupaten Probolinggo.

Tabel 1. Observasi

\begin{tabular}{|c|l|l|}
\hline Tanggal & \multicolumn{1}{|c|}{ Bagian } & \multicolumn{1}{c|}{ Kegiatan } \\
\hline 05 Maret 2021 & Bidang Binamarga & $\begin{array}{l}\text { Mengamati proses pencarian } \\
\text { data kerusakan jalan }\end{array}$ \\
\hline
\end{tabular}

b. Wawancara

Dengan melakukan tanya jawab dengan pihak yang bersangkutan untuk memperoleh beberapa masukan dan penyelidikan mendalam terkait pengembangankan aplikasi.

Tabel 2. Wawancara

\begin{tabular}{|c|c|l|}
\hline Tanggal & Bagian & \multicolumn{1}{c|}{ Kegiatan } \\
\hline 05 Maret 2021 & Bidang Binamarga & - Bagaimana cara untuk melihat data kerusakan \\
& & jalan? \\
& & - Apa semua ruas jalan yang ada di kabupaten \\
& & Probolinggo ditangani oleh dinas pupr ? \\
& & - Apa saja kategori tingkat kerusakan jalan ? \\
& & - Siapa yang melakukan pelaporan/ pencatatan \\
& & kerusakan jalan? \\
\hline
\end{tabular}


c. Studi Pustaka

Dengan membaca berbagai buku atau refrensi yang berhubungan dengan penyusunan skripsi ini yang dalam hal ini diperlukan untuk mendukung suatu teori yang akan digunakan dalam menyelesaikan masalah mengenai sistem yang akan dibuat. Pada penelitian ini mengambil informasi

\subsection{Teknik Pengembangan}

Di dalam pengembangan suatu sistem diperlukan adanya suatu metode yang sesuai dengan kebutuhannya, sehingga dengan mengikuti suatu metode terdapat prosedur-prosedur yang dapat dilakukan, adapun dalam melakukan pengembangan sistem ini akan menggunakan metode Waterfall.

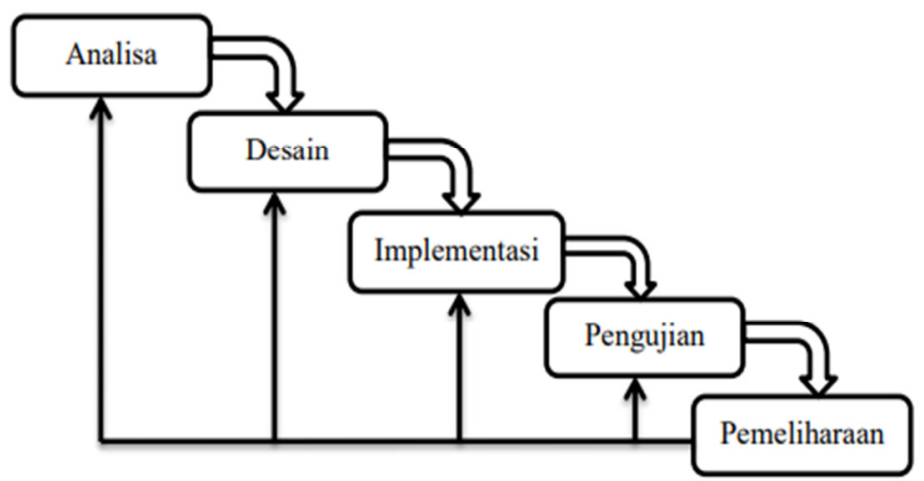

Gambar 2. Metode Waterfall

\section{HASIL DAN PEMBAHASAN}

3.1 Hasil Pengumpulan Data [2]

a. Hasil Observasi

Tabel 3. Hasil Observasi

\begin{tabular}{|c|c|}
\hline Uraian Kegiataan & Hasil Kegiatan \\
\hline $\begin{array}{l}\text { Mengamati proses pencarian data } \\
\text { kerusakan jalan }\end{array}$ & $\begin{array}{l}\text { Selama ini untuk melihat data kerusakan } \\
\text { jalan yang ada yaitu menggunakan data } \\
\text { base yang tersimpan dalam bentuk } \\
\text { dokumen. Dalam dokumen tersebut } \\
\text { terdapat beberapa informasi mengenai } \\
\text { kerusakan jalan yang ada seperti, alamat, } \\
\text { titik kordinat, tingkat kerusakan jalan dan } \\
\text { juga foto kerusakan jalan. Untuk mencari } \\
\text { kerusakan jalan harus mencarinya satu } \\
\text { persatu sesuai kecamatan. }\end{array}$ \\
\hline
\end{tabular}

Rofi'ah, et., al [Sistem Informasi Geografis Pemetaan Kerusakan Jalan Berbasis Web dan Android] 
b. Hasil Wawancara

Tabel 4. Hasil Wawancara

\begin{tabular}{|c|c|c|}
\hline No & Pertanyaan & Hasil Kegiatan \\
\hline 1. & $\begin{array}{l}\text { Bagaimana cara untuk melihat } \\
\text { data kerusakan jalan? }\end{array}$ & $\begin{array}{l}\text { Dengan membuka database yang berupa } \\
\text { dokumen digital. Melakukan pencarian } \\
\text { berdasarkan kecamatan satu persatu }\end{array}$ \\
\hline 2. & $\begin{array}{l}\text { Apa semua ruas jalan yang ada di } \\
\text { kabupaten Probolinggo ditangani } \\
\text { oleh dinas pupr? }\end{array}$ & $\begin{array}{l}\text { Tidak, ruas jalan yang ditangani dinas pupr } \\
\text { hanya ruas jalan kabupaten }\end{array}$ \\
\hline 3. & $\begin{array}{l}\text { Apa saja kategori tingkat } \\
\text { kerusakan jalan? }\end{array}$ & $\begin{array}{l}\text { Kategori tingkat kerusakan jalan ada } 2 \text { yaitu, } \\
\text { biasa dan parah }\end{array}$ \\
\hline 4. & $\begin{array}{l}\text { Siapa yang melakukan } \\
\text { pelaporan/pencatatan kerusakan } \\
\text { jalan? }\end{array}$ & $\begin{array}{l}\text { Tidak ada kewajiban laporan kerusakan jalan } \\
\text { yang harus dilaporkan kepada siapapun, karena } \\
\text { setiap bulan ada kegiatan survei ruas jalan } \\
\text { untuk melihat kondisi jalan yang ada yang } \\
\text { dilakukan oleh petugas lapangan staf bidang } \\
\text { binamarga }\end{array}$ \\
\hline
\end{tabular}

\subsection{Hasil Pengembangan Sistem}

1. Analisi Kebutuhan Sistem

a. Kebutuhan Fungsional

- Petugas lapangan atau user dapat mengirimkan foto dan titik kordinat kerusakan jalan menggunakan aplikasi android yang disediakan.

- Petugas atau admin dapat melihat foto dan titik kordinat kerusakan jalan yang dikirimkan ke apliaksi web yang telah disediakan.

- Pegawai atau admin dapat mengkonfirmasi dan menghapus data kerusakan yang ada didalam aplikasi web.

b. Kebutuhan Non-Fungsional

a) Kebutuhan Perangkat Keras (hardware) Perangkat Keras yang digunakan selama proses penelitian berlangsung adalah sebagai berikut:

- 1 Unit Laptop Acer, RAM 4,00GB Type 64-bit Operating System.

- Flasdisk merek ADATA berkapasitas 8GB

b) Kebutuhan Perangkat Lunak (Software) Selain Perangkat Keras (Hardware) dalam pembuatan aplikasi ini dibutuhkan Perangkat Lunak. Adapun software yang dibutuhkan adalah sebagai berikut -

- Web Server (Apache) XAMPP

- Database (MySQL)

- Mozilla Firefox

- Android Studio

- Visual Studio Code

2. Desain Sistem [3]
1. Flowchart 


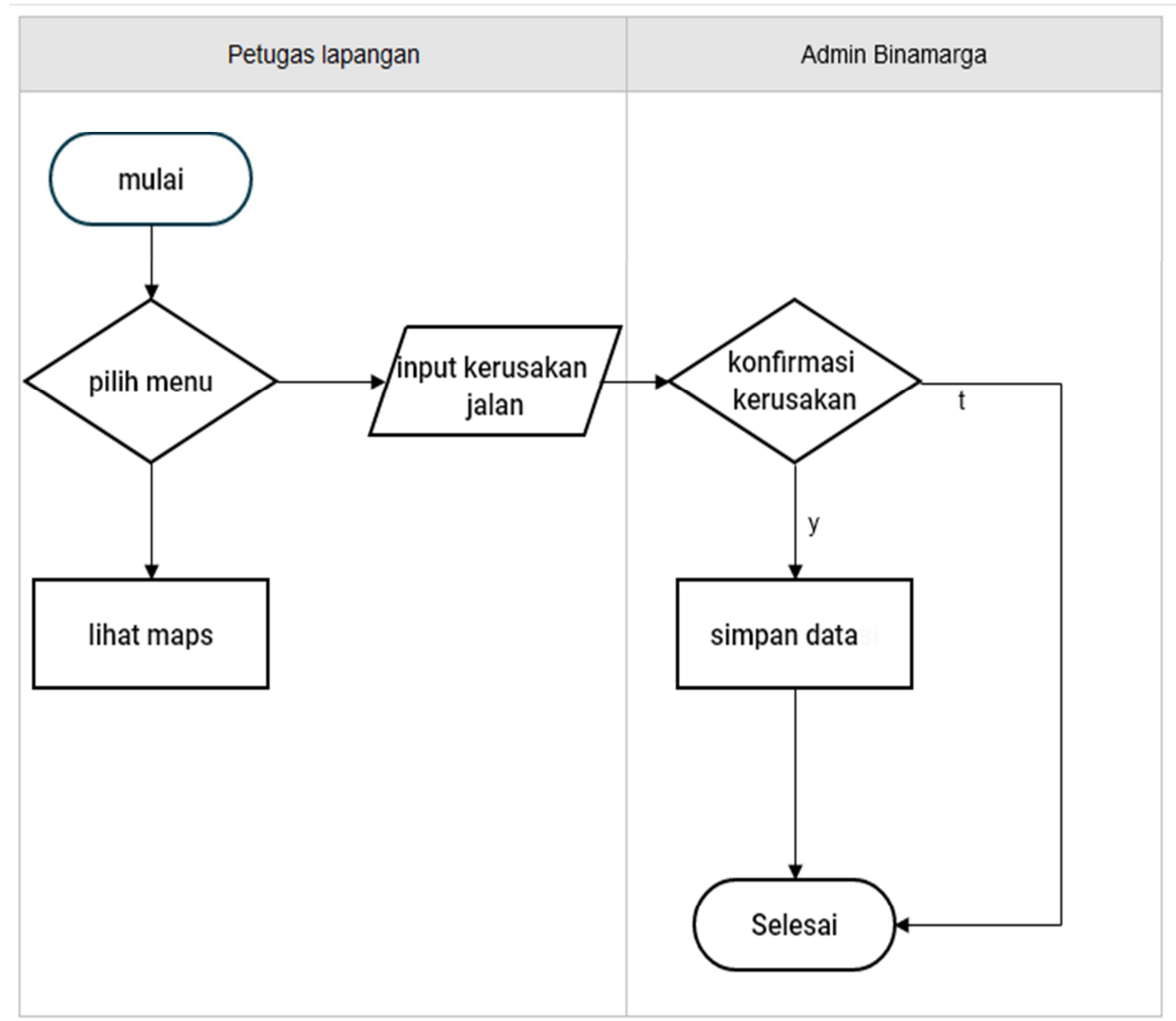

Gambar 3. Flowchart Sistem

2. Data Flow Diagram (DFD)

a. Context Diagram

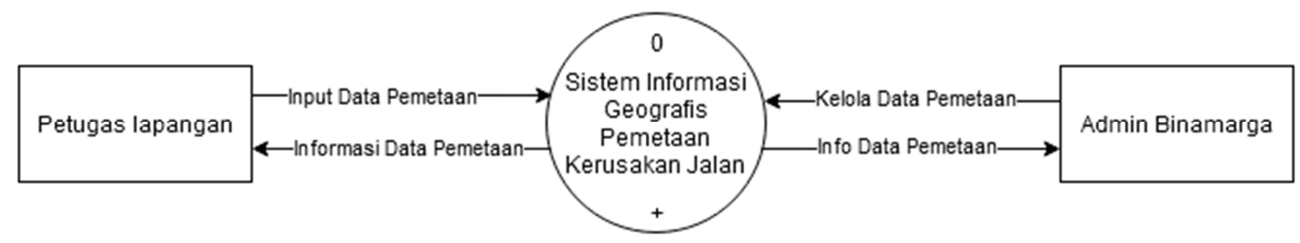

Gambar 4. Context Diagram

b. Bagan berjenjang 


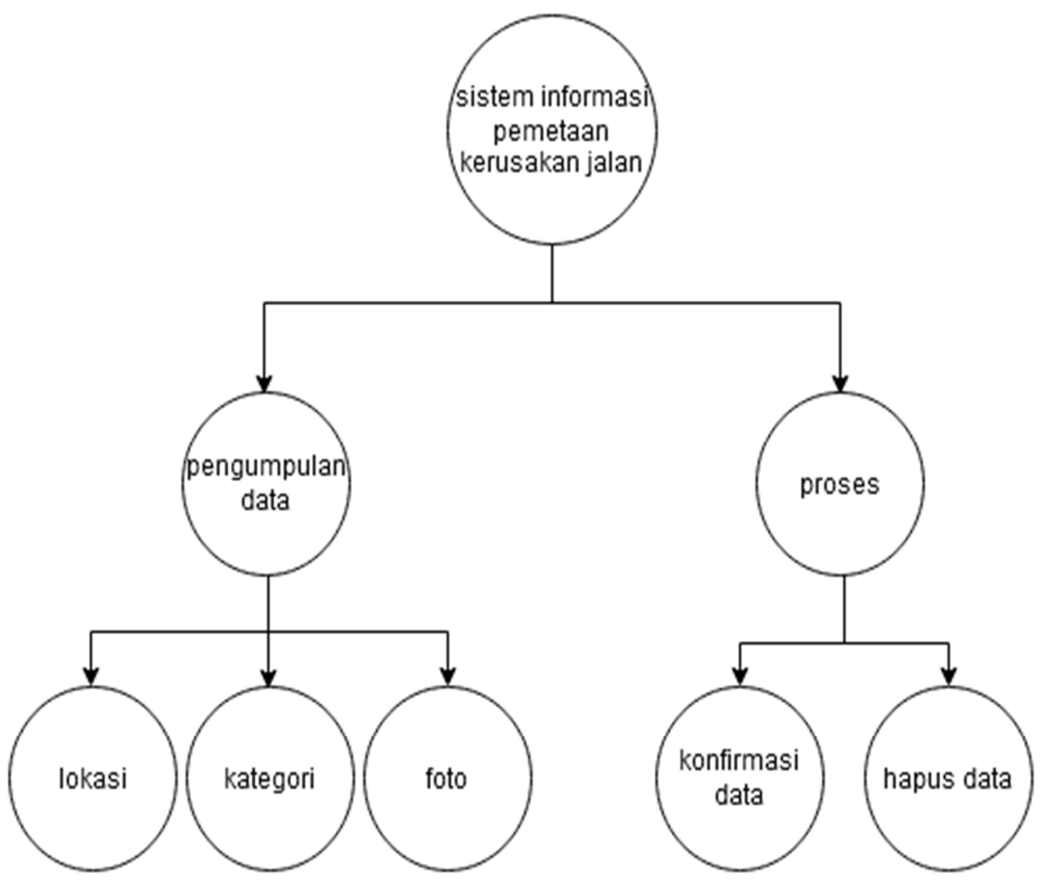

Gambar 5. Bagan Berjenjang

c. DFD Level 1

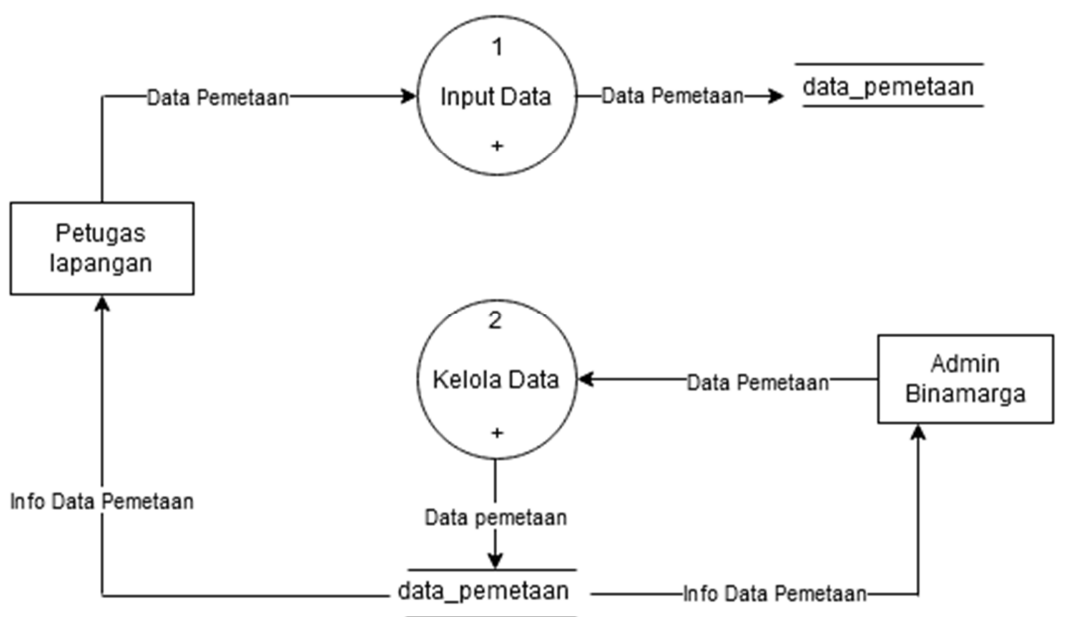

Gambar 6. DFD Level 1

d. DFD Level 2 Proses 1

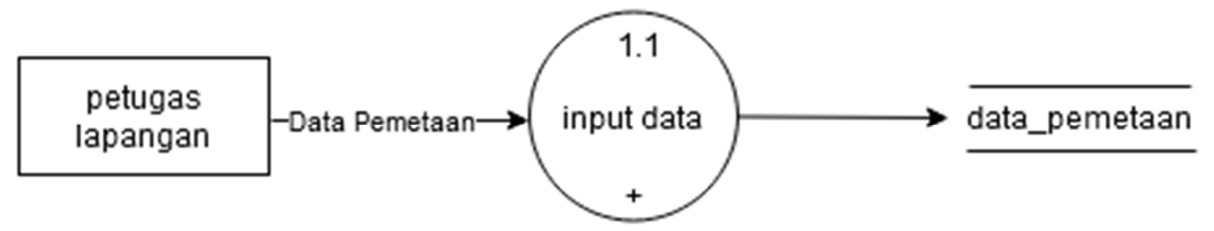

Gambar 7. DFD Level 2 Proses 1 
e. DFD Level 2 Proses 2

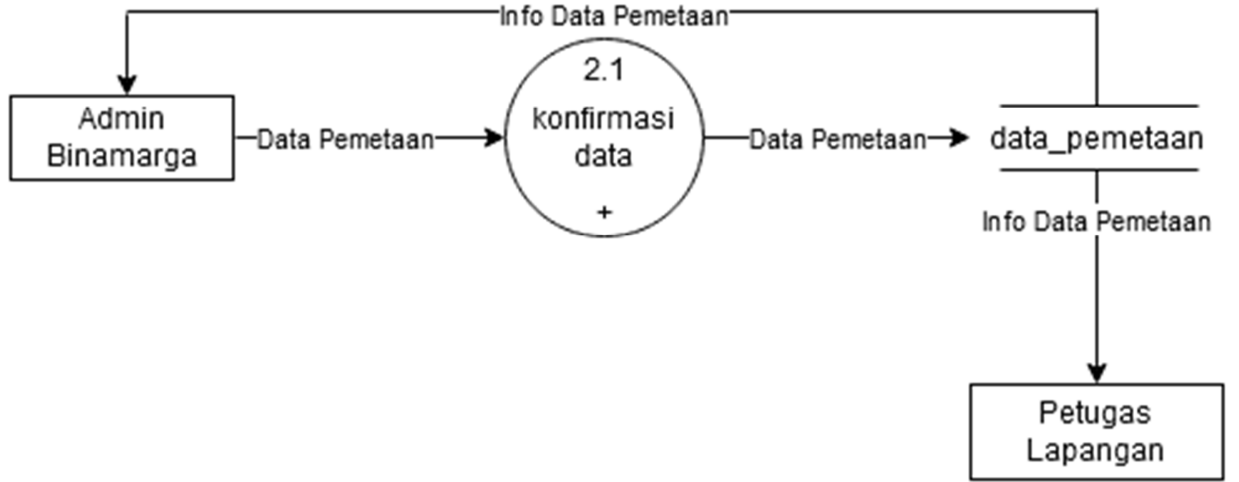

Gambar 8. DFD Level 2 Proses 1

\section{Entity Relationship Diagram (ERD)}

Sistem informasi terdiri dari beberapa entitas yang merupakan komponen dasar dari suatu sistem. Entitas-entitas yang ada tersebut saling mendukung dan memiliki keterkaitan satu dengan yang lain. Cara menggambarkan hubungan antar entitas adalah dengan menggunakan entity relationship digram. Entity Relationship Diagram akan dapat memahami hubungan Many To Many, One To Many, dan One To One, sehingga ada pemahaman terhadap entitas secara jelas dan mudah. Diagaram disini akan dilengkapi kamus data, sehingga atribut-atribut yang digaris bawah menjadi kunci atau key. [3]

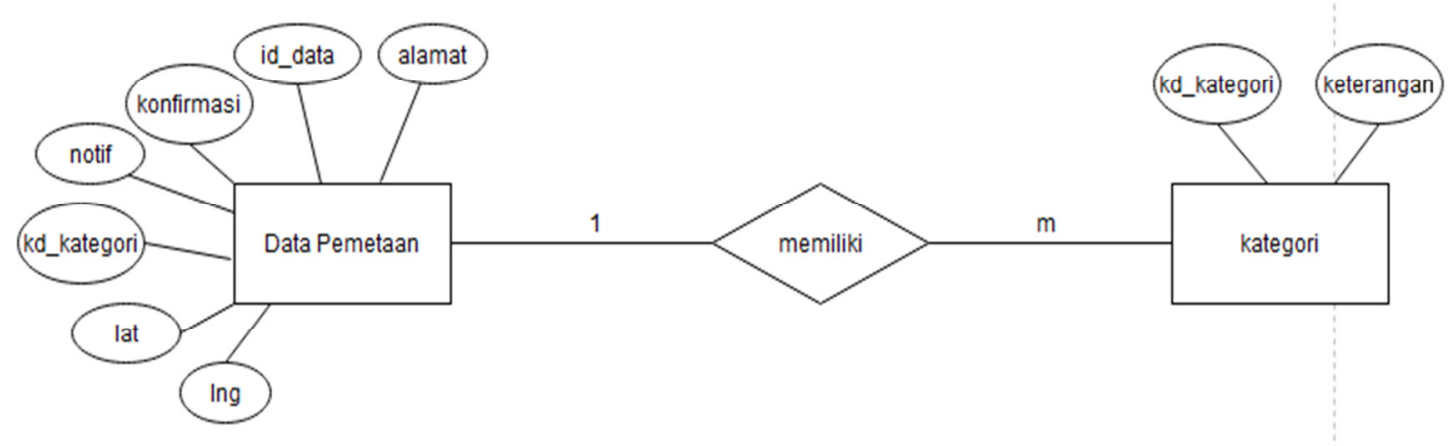

Gambar 9. Entity Relationship Diagram

Kamus data:

Data_pemetaan : id_data, alamat, notif, konfirmasi, kategori, lat, lng Tbl_kategori : kd_kategori, keterangan

4. Implementasi

1. Desain Android 


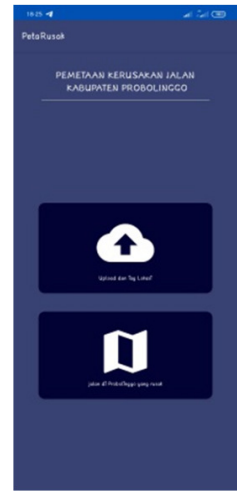

Tampilan Menu
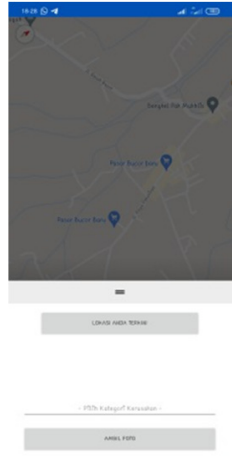

Input Data

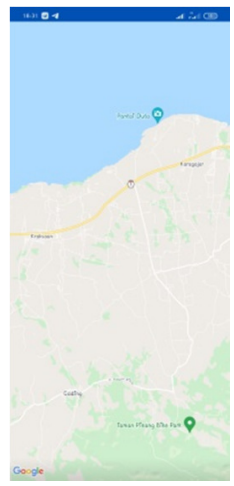

Maps Pemetaaan

Gambar 10. Implementasi Android

2. Implementasi $W e b$

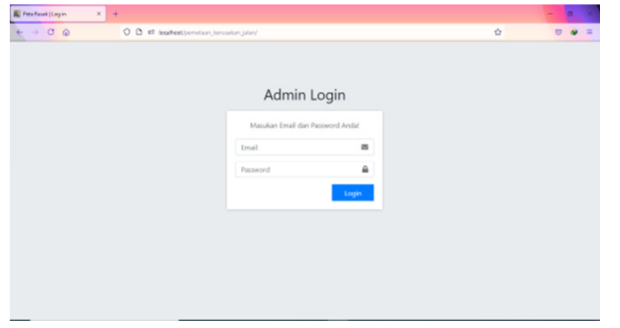

Tampilan Login

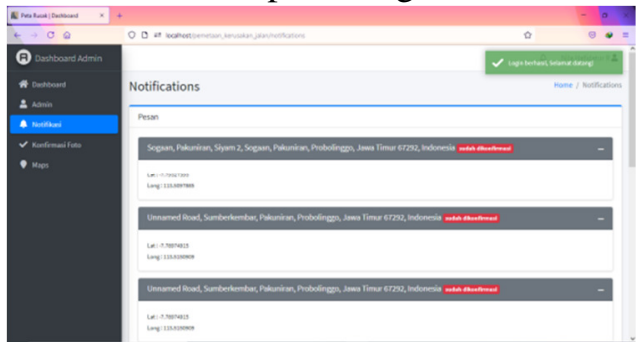

Tampilan Notifikasi

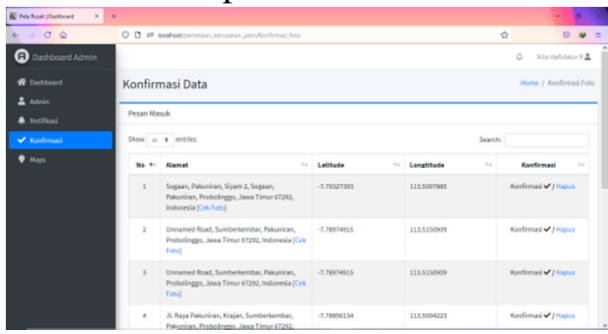

Tampilan Konfirmasi Data

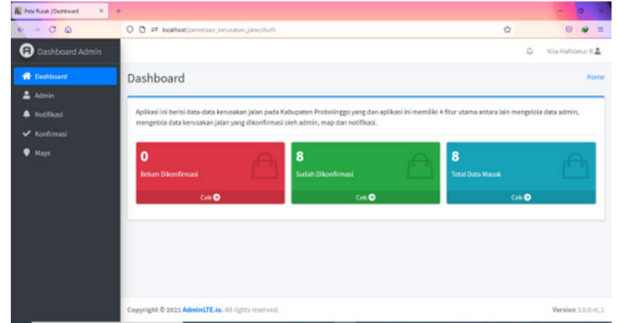

Tampilan Dasboard

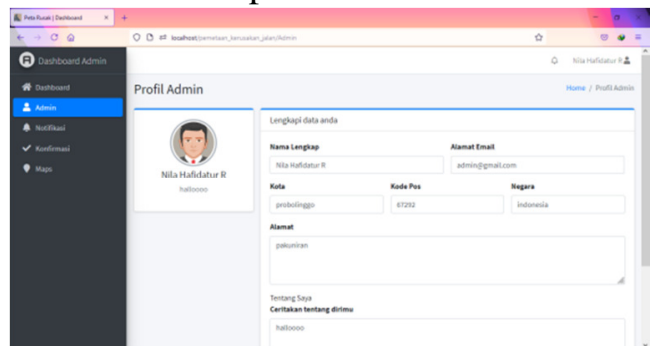

Tampilan Profil Admin

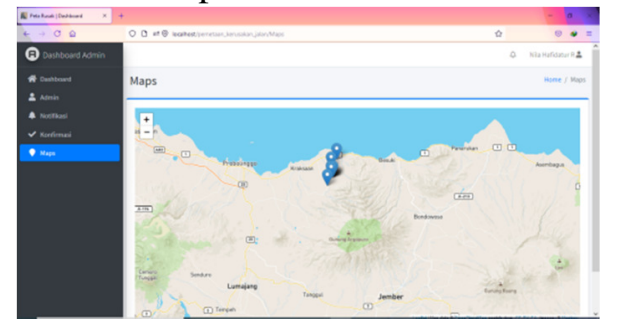

Tampilan Maps Pemetaan

Gambar 11. Implementasi Web

5. Pengujian Sistem [4] 
Tabel 5. Hasil Pengujian

\begin{tabular}{|c|l|c|c|c|c|c|}
\hline \multirow{2}{*}{ No. } & \multicolumn{1}{|c|}{ Pertanyaan } & \multicolumn{4}{|c|}{ Jawaban } \\
\cline { 2 - 6 } 1. & $\begin{array}{c}\text { Sangat } \\
\text { Baik }\end{array}$ & Baik & Cukup & Kurang & $\begin{array}{c}\text { Sangat } \\
\text { Kurang }\end{array}$ \\
\hline $\begin{array}{l}\text { Apakah sistem ini } \\
\text { dalam melihat data pemetaan } \\
\text { kerusakan jalan ? }\end{array}$ & 1 & 3 & 1 & 0 & 0 \\
\hline 2. & $\begin{array}{l}\text { Apakah aplikasi ini dapat } \\
\text { membantu petugas lapangan } \\
\text { ? }\end{array}$ & 0 & 4 & 1 & 0 & 0 \\
\hline 3. & $\begin{array}{l}\text { Apakah aplikasi layak untuk } \\
\text { dipakai ? }\end{array}$ & 0 & 2 & 3 & 0 & 0 \\
\hline 4. & $\begin{array}{l}\text { Apa ada kendala dalam } \\
\text { mengoprasikan aplikasi ini ? }\end{array}$ & 0 & 3 & 2 & 0 & 0 \\
\hline 5. & $\begin{array}{l}\text { Apa aplikasi ini memberi } \\
\text { laporan yang benar ? }\end{array}$ & 0 & 5 & 0 & 0 & 0 \\
\hline
\end{tabular}

Tabel 6. Kuesioner

\begin{tabular}{|c|c|c|l|l|l|l|l|}
\hline \multirow{2}{*}{ No. } & \multirow{2}{*}{ Pendaftar } & \multicolumn{5}{|c|}{ Jawaban Pertanyaan ke } & \multirow{2}{*}{ Total } \\
\cline { 3 - 8 } & & Q1 & Q2 & Q3 & Q4 & Q5 & \\
\hline 1. & Responden 1 & 2 & 3 & 3 & 3 & 3 & 14 \\
\hline 2. & Responden 2 & 3 & 2 & 3 & 3 & 3 & 14 \\
\hline 3. & Responden 3 & 4 & 3 & 2 & 2 & 3 & 14 \\
\hline 4. & Responden 4 & 3 & 3 & 2 & 3 & 3 & 14 \\
\hline 5. & Responden 5 & 3 & 3 & 2 & 2 & 3 & 13 \\
\hline
\end{tabular}

Hasil wawancara dari 5 responden dan 5 pertanyaan di dapatkan data sebagai berikut :

1. 1 Menjawab SB (Sangat Baik)

2. 17 Menjawab B (Baik)

3. 7 Menjawab C (Cukup)

4. 0 Menjawab K (Kurang)

5. 0 Menjawab SK (Sangat Kurang)

Bobot nilai / skor skala linkert :

3. $\mathrm{SB}($ Sangat baik $)=5$

4. $\mathrm{B}($ Baik $)=4$

5. $\mathrm{C}($ Cukup $)=3$

6. $\mathrm{K}($ Kurang $)=2$

7. SK (Sangat kurang) $=1$ 
Tabel 7. Persetase Nilai

\begin{tabular}{|l|l|}
\hline \multicolumn{1}{|c|}{ Jawaban } & \multicolumn{1}{c|}{ Keterangan } \\
\hline $0 \%-19,99 \%$ & Sangat Tidak Layak \\
\hline $20 \%-39,99 \%$ & Tidak Layak \\
\hline $40 \%-59,99 \%$ & Cukup Layak \\
\hline $60 \%-79,99 \%$ & Layak \\
\hline $80 \%-100 \%$ & Sangat Layak \\
\hline
\end{tabular}

Jumlah skor pengujian merupakan jumlah asal skor tiap butir pertanyaan akibat pengujian yang dikalikan dengan bobot skor menurut skala Likert. Skor aporisma merupakan skor maksimal pada skala likert yang dikalikan dengan jumlah butir soal, sehinnga lima x $5=$ 25. Jumlah skor uang diharapkan adalah skor aporisma yang dikalikan menggunakan jumlah responden, sebagai akibatnya lima x $25=125$. Perhitungan presentasi kelayakan menggunakan rumus menjadi berikut:

$$
\begin{aligned}
& \text { Total Skor }=(\text { jumlah } x \text { skorSB })+(\text { jumlah } x \text { skor } B)+(\text { jumlah } x \operatorname{skor} C) \\
& +(\text { jumlah } x \text { skorK })+(\text { jumlah } x \text { skorSK })
\end{aligned}
$$

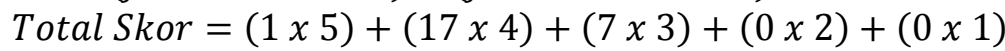

$$
\begin{aligned}
& \text { Total Skor }=94
\end{aligned}
$$

Sedangkan presentase kelayakan dari para penguji adalah sebagai berikut:

$$
\begin{gathered}
\text { Presentase kelayakan }=\frac{\text { Total Skor }}{\text { Skor Yang Diharapkan }} \times 100 \\
\text { Presentase kelayakan }=\frac{94}{125} \times 100 \\
\text { Presentase kelayakan }=75,2 \%
\end{gathered}
$$

Total skor pengujian dari data pengujian sejumlah 94 (75,2\%) dari skor yang diharapkan yaitu 125 (100\%). Berdasarkan kriteria pada tabel kelayalan menurut Arinkunto (2009). Presentase total skor tersebut termasuk dalam kategori layak.

\section{KESIMPULAN}

Kesimpulan dari penelitian yang berjudul Sistem Informasi Geografis Pemetaan Kerusakan jalan Berbasis Web dan Android adalah menghasilkan sebuah sistem yang mampu membantu Dinas PUPR dalam memetakan kerusakan jalan yang ada di Kabupaten Probolinggo guna mempermudah dalam pencarian data kerusakan jalan yang ada berbasis web dan android. Berdasarkan hasil pengujian eksternal memperoleh hasil persentase sebesar 75,2\% yang artinya sistem ini Layak untuk digunakan.

\section{SARAN}

Adapun saran yang diharapkan untuk membantu kesempurnaan penelitian ini diharapkan adanya pengembangan dari program yang ada dengan tambahan fitur ataupun menu tambahan pada website agar program menjadi lebih sempurna. 


\section{UCAPAN TERIMA KASIH}

Penulis sampaikan terima kasih yang sebesar-besarnya kepada pihak Dinas PUPR yang telah memperkenankan daam melakukan penelitian dan semua pihak yang telah mendukung, sehingga penulis dapat menyelesaikan Sistem Informasi Pemetaan Kerusakan Jalan Berbasis Android dan Web

\section{DAFTAR PUSTAKA}

[1] DPUPR. 2021 Dinas Pekerjaan Umum dan Penataan Ruang Kabupaten Probolinggo. Website Pemkab Probolinggo

[2] Sarwono, J. 2006. Metode Penelitian Kuantitatif dan Kualitatif.

[3] Jogiyanto, H. M. 2017. Analisis dan Desain (Sistem Informasi Pendekatan Terstruktur Teori dan Praktek Aplikasi Bisnis). Andi, Yogyakarta.

[4] Arikunto, S., 2009. Prosedur Penelitian Suatu Pendekatan Praktik. Edisi Revisi 6. Rineka Cipta, Jakarta.

[5] Hasanuddin, H. A. H. H. A., \& Ridwan, V. F. R. V. F. 2018, Pemetaan Terpadu Sistem Informasi Geografis Pemetaan Jalan Kota Takalar, In Seminar Nasional Hasil Penelitian \& Pengabdian Kepada Masyarakat (SNP2M). 